\title{
原蓶
}

\section{遺族サポートグループにおける参加者の心理プロセスと その促進要因に関する質的研究}

\author{
大和田攝子 ${ }^{11}$, 大和田康二 ${ }^{2)}$, 加山 寿也 ${ }^{3)}$, 城下 安代 ${ }^{4}$
}

1) 神戸松蔭女子学院大学 人間科学部心理学科, 2) 尼崎医療生協病院 臨床心理部, 3) 同 緩和ケア科, 4) 同 看護部

受付日 2013 年 6 月 11 日/改訂日 2013 年 8 月 12 日/受理日 2013 年 8 月 13 日

\begin{abstract}
本研究の目的は, 緩和ケア病棟が主催する遺族サポートグループの参加者における心理プロセスとその促進要因につい て検討することである. 全 12 回のセッションの中で 12 名の参加者によって語られた言語データを修正版グラウンデッド. セオリー・アプローチによって分析し, グループに参加することで彼らの中に生じた変化や, グループが及ぼす影響につい て検討した. その結果, 145 の概念, 20 のサブカテゴリー, 7 のカテゴリーが生成され, 参加者の心理プロセスが明らかに なった. 全体的な流れとして,【死別後の生活上の困難】【故人に対する想いの表出】【現実生活の情報交換】【死別後のナラ ティブの再編】【体験を通した悲嘆反応の客観化】【死別後の肯定的変化】という一連の過程が見出され、【グループ相互作 用によるエンパワメント】がそれらの変化の促進要因となっていることが示唆された.

Palliat Care Res 2013; 8(2): 254-63
\end{abstract}

Key words: 遺族サポートグループ, 緩和ケア, 修正版グラウンデッド・セオリー・アプローチ

\section{緒 言}

2007 年に「がん対策基本法」が施行され, 緩和ケアの普及 と質の向上が, がん医療における最も重要な課題の 1 つとされ た. その中でも遺族ケアは, 緩和ケアが担う大きな役割の 1 つ であり,わが国でも多くのホスピス・緩和ケア病棟においてさ まざまな遺族ケアの取り組みが行われている ${ }^{1)}$. しかし, 個々の 遺族の状況に合わせた専門的な関わりや援助を組織として提 供している施設はほとんどないのが現状である.

尼崎医療生協病院 (以下, 当院) では, 遺族ケアプログラムの 一環として遺族サポートグループの運営を行ってきた ${ }^{2)}$. 遺族 のためのサポートグループは, 同じ悲しみをもつ仲間同士がそ れぞれの思いを語り合うことによって, 共に悲嘆からの回復へ

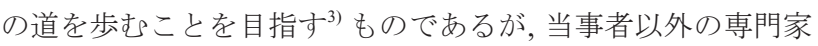
によって運営される点がセルフヘルプグループとの大きな違 いである ${ }^{4)}$. サポートグループの有効性については, 複雑性悲嘆 など精神症状の軽減に一定の役割を果たすことが報告されて いる5)が, グループの中で何が起こり, 参加者の心理プロセス にどのような影響をもたらすのかについて詳細に検討したも のは散見される程度である゙

そこで本研究では, グループにおいて語られた会話の内容を 質的に分析し, 参加者にどのような変化が起こり, またグルー プは参加者の心理プロセスにどのような影響をもたらすのか について検討する.

\section{方 法}

\section{1 遺族サポートグループの構造}

遺族サポートグループ「ハナミズキの会」は当院緩和ケア 科主催として位置づけられ, 筆者らが中心となって運営してい る.グループの形態は, メンバーを固定し, セッションの回数を 月 1 回 (全 12 回) に限定した closed group である.

\section{1. 対象者}

対象者は当院において,がんで家族を亡くした遺族である. 2009 年 10 月ー 2010 年 9 月にかけて家族を看取った遺族にサ ポートグループの案内とスクリーニングのための調査票を送 付し, 参加者を募集した. 故人との関係は問わないが, 複雑性悲 嘆のスクリーニングに必要な死別後 6 カ月以上 ${ }^{7}$ 経過してい ることが条件である。

\section{2. プログラムの内容}

プログラムは基本的に参加者の語り合いが中心となるが, 死 別や悲嘆に関する心理教育 (小講義 \#1-8) と悲嘆の促進に有 効な技法 (ワーク \#1-2) を織り交ぜながら進めている.

時間配分は, 小講義を 20 分程度, 語り合いの時間を 90 分設 けている (表 1). 語り合いでは, ファシリテーターは参加者 1 人ひとりの体験を尊重し傾聴する姿勢を心がけた.

\section{3. 実施期間}

2011 年 4 月ー 2012 年 3 月までの月 1 回 (第 2 土曜), 14:00 16:00.

\section{4. 運営方法}

筆者 (外部の臨床心理士) と当院の臨床心理士がグループの 運営とファシリテーターを担当した. また, 心理学専攻の大学

\footnotetext{
Corresponding author: 大和田攝子 $\mid$ 神戸松蔭女子学院大学人間科学部心理学科

厂 657-0015 兵庫県神戸市灘区篠原伯母野山町 1-2-1

TEL 078-882-6122 FAX 078-882-5032 E-mail: setsuko@shoin.ac.jp
} 
表 1 遺族サポートグループのプログラムの内容

\begin{tabular}{|c|c|}
\hline 第 1 回 & オリエンテーション (基本ルールの説明), 自己紹介 \\
\hline 第 2 回 & 小講義＃1 死別後に生じること＆語り合い \\
\hline 第 3 回 & 小講義＃2＼cjkstart悲嘆に影響を及ぼす要因＆語り合い \\
\hline 第 4 回 & 小講義 \#3 通常の悲嘆反応と複雑な悲嘆反応＆語り合い \\
\hline 第 5 回 & 小講義＃4 悲嘆とうつの違い\&語り合い \\
\hline 第 6 回 & 小講義＃5 回復に役立つこと＆語り合い \\
\hline 第 7 回 & 小講義＃6 感情表現の方法＆語り合い \\
\hline 第 8 回 & ワーク\#1 故人の写真や遺品を持ち寄り，想いを語る \\
\hline 第 9 回 & ワーク＃2 故人に対して手紙を書き, 読み上げる \\
\hline 第 10 回 & 小講義＃7 回復へのプロセス＆語り合い \\
\hline 第 11 回 & 小講義 \#8 死別後の成長 \& 語り合い \\
\hline 第 12 回 & まとめ \\
\hline
\end{tabular}

院生などが会場設営や受付, 記録などを担当した。場所は遺族 の心情に配慮して, 当院より少し離れた建物の多目的室を使用 した.

\section{5. 基本ルール}

「語られた内容に関して秘密を守る (守秘義務)」「誰かが話 している時はさえぎらないで聞く」などの基本ルールを会則 に明記し, 初回のオリエンテーションの際に参加者に説明し た.

\section{2 データ収集および分析方法}

本研究では, データに密着した分析から独自の理論を生成す る質的研究法として修正版グラウンデッド・セオリー・アプ ローチ (以下, M-GTA) $)^{8)}$ を採用した. 以下に分析手順を示す.

まず, 遺族サポートグループで参加者が語った発言を ICレ コーダーで録音し (事前に録音の承諾済み), 逐語記録を作成す る. そのデータをもとに, 分析テーマ (本研究では「遺族サポー トグループにおける参加者の心理プロセス」)に照らし合わせ ながら概念生成を行う. その際, 分析ワークシートを作成し, 概 念名, 定義, 具体例を記入する.このオープン・コード化で概念 生成を進めつつ, 並行して概念間の関係を検討していく.ある 程度の概念間のまとまりをカテゴリーといい, ある現象を説明 する意味のまとまりとしてカテゴリーにまとめる. さらに, カ テゴリー相互の関係から中核的なカテゴリーを見出し, 分析結 果を構成する. 最終的に分析結果をまとめたストーリーライン を作成し, 結果の概念図を作成するものである.

なお, M-GTA の分析にあたっては染意的な解釈を防ぐため, 複数の専門家により共同で分析作業を進めた.

\section{3 倫理的配慮}

遺族サポートグループの参加者に研究の主旨および任意性, 倫理面への配慮などを口頭で説明し, 承諾を得た. なお, 本研究 の実施にあたっては, 当院に設置されている倫理委員会の承認 を得た.

\section{結 果}

1 遺族サポートグループ参加者の属性と参加状況

遺族サポートグループの参加者は 12 名 (男性 4 名, 女性 8
表 2 遺族サポートグループ参加者の属性と参加状況

\begin{tabular}{c|c|c|c|c|c}
\hline 参加者 & 性別 & 年齢 & $\begin{array}{c}\text { 故人との } \\
\text { 続柄 }\end{array}$ & 経過月数 & 参加回数 \\
\hline A & 女 & 75 & 夫 & 17 & 12 \\
\hline B & 女 & 74 & 夫 & 7 & 11 \\
\hline C & 男 & 59 & 娘 & 6 & 1 \\
\hline D & 女 & 56 & 娘 & 6 & 4 \\
\hline E & 女 & 74 & 夫 & 15 & 10 \\
\hline F & 女 & 67 & 夫 & 12 & 5 \\
\hline G & 男 & 69 & 妻 & 7 & 9 \\
\hline H & 女 & 63 & 母 & 6 & 1 \\
\hline I & 男 & 70 & 息子 & 16 & 5 \\
\hline J & 女 & 59 & 夫 & 10 & 11 \\
\hline K & 男 & 63 & 妻 & 12 & 1 \\
\hline L & 女 & 70 & 夫 & 9 & 5 \\
\hline
\end{tabular}

名), 平均年齢は 66.6 歳 $(\mathrm{SD}=6.5)$ であった. 故人との続柄は配 偶者が 8 名 $(66.7 \%)$ と最も多く, 死別後の経過月数は平均 10.3 力月 $(\mathrm{SD}=4.1)$ であった. また, 各回の参加者数は 4-9 名で, 延べ参加者数は 75 名であった (表 2).

2 カテゴリー, サブカテゴリー, 概念の生成

M-GTAによる分析の結果, 遺族サポートグループ全 12 回 の発言データから 145 の概念, 20 のサブカテゴリー, 7 のカテ ゴリーが生成された (表 3). 各カテゴリーは【 【, サブカテゴ リーはく〉, 概念は番号と“”で示した.

\section{カテゴリー 1: 【死別後の生活上の困難】}

このカテゴリーは, グループ開始当初から話されることが多 い. 〈死別後の生活で直面する寂しさやつらさ〉は, “1. 配偶者 のいない生活に対する負担や寂しさ” など, 実生活での慣れな い役割の負担に加え, 食事や洗濯, 入浴, 入眠時など死別の寂し さを 1 人で抱えるつらさなどが共有される. 参加者の中には死 別により自由を獲得したと表明する人もおり，〈生活の依存度 による適応の違い〉についても話題が及んだ. その中で, “27. 
表 3 本研究で見出されたカテゴリー, サブカテゴリー, 概念, バリエーション (具体例) の一部

\begin{tabular}{|c|c|c|c|}
\hline カテゴリー & サブカテゴリー & 概念 & バリエーション (具体例) \\
\hline \multirow{4}{*}{$\begin{array}{l}\text { 死別後の } \\
\text { 生活上の困難 }\end{array}$} & \begin{tabular}{|l|} 
死別後の生活で直面 \\
する寂しさやつらさ
\end{tabular} & $\begin{array}{l}\text { 1. 配偶者のいない生活に対 } \\
\text { する負担や寂しさ } \\
\text { 17. 死別後の悲しみや寂しさ }\end{array}$ & $\begin{array}{l}\text { 「何もできんもんやから重荷で. 一人になってしまって非常に } \\
\text { 困っていました」(G) } \\
\text { 「今年三回忌. そうなってくると, 一人になってくると寂しさが } \\
\text { 押し寄せてくる. スーッと. 亡くなってすぐの方がすることたく } \\
\text { さんあるから, そんなことは考えなかった. 元気そうに見えてだ } \\
\text { んだん寂しくなってきた. } 1 \text { 年目より } 2 \text { 年目の方がしんどいで } \\
\text { す」(A) }\end{array}$ \\
\hline & $\begin{array}{l}\text { 生活の依存度による } \\
\text { 適応の違い }\end{array}$ & $\begin{array}{l}\text { 27. 男女における生活力の違 } \\
\text { い } \\
\text { 135. 男性特有のつらさ }\end{array}$ & $\begin{array}{l}\text { 「なんや言っても女性の生活力は男の倍ある. 長年付き添った夫 } \\
\text { が亡くなったら, さあ今からが青春という方もいるが, その方が } \\
\text { いい」(I) } \\
\text { 「男の人はちょっと構えて, いい恰好してしまう. 年いっても同 } \\
\text { じやもん. 大変, ほんま大変ですね」(G) }\end{array}$ \\
\hline & $\begin{array}{l}\text { 死別後の生活の多忙 } \\
\text { と不安 }\end{array}$ & $\begin{array}{l}\text { 23. 死別後における悲しむ睱 } \\
\text { もないほどの多忙 } \\
\text { 68. 死別後の諸手続きに対す } \\
\text { る不安や大変さ }\end{array}$ & 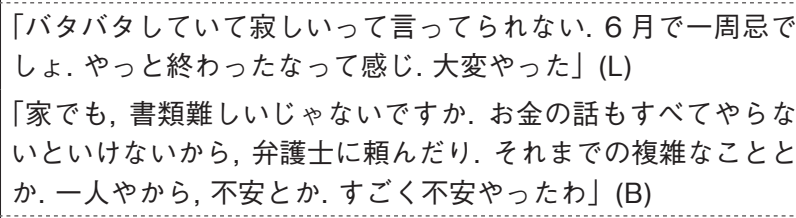 \\
\hline & $\begin{array}{l}\text { 今後の生活について } \\
\text { 摇れ動く気持ち }\end{array}$ & $\begin{array}{l}\text { 16. 前向きに生きなければな } \\
\text { らないという気持ち } \\
\text { 112. 新しいことを始めること } \\
\text { への罪悪感 } \\
\text { 144. 前向きになれない }\end{array}$ & $\begin{array}{l}\text { 「毎日クヨクヨしても仕方ないから, 前向きで楽しいこと考え } \\
\text { て」(B) } \\
\text { 「新しいこと始めたら, 後ろめたさというか. 忘れてほしくない } \\
\text { という気持ちと違う世界にいるので」(J) } \\
\text { 「なんか自分で, これじゃあかん,って前向きにと思うが, なられ } \\
\text { へん」(E) }\end{array}$ \\
\hline \multirow{7}{*}{$\begin{array}{l}\text { 故人に対する } \\
\text { 想いの表出 }\end{array}$} & \begin{tabular}{|l|} 
闘病から看取り, 死 \\
別に際して感じた満 \\
足感や感謝
\end{tabular} & $\begin{array}{l}\text { 52. 納得のいくがん医療を受 } \\
\text { けられたことに対する満 } \\
\text { 足 } \\
\text { 99. 希望通りの葬式 }\end{array}$ & 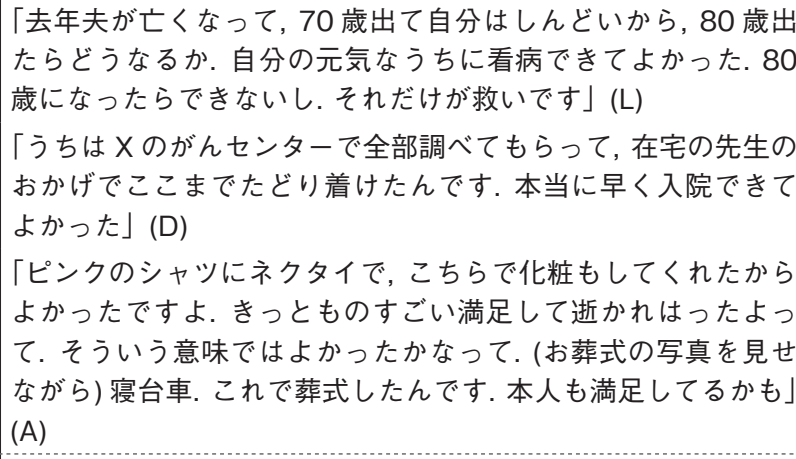 \\
\hline & $\mid \begin{array}{l}\text { 闘病から看取り, 死 } \\
\text { 別に際して感じた否 } \\
\text { 定的感情 }\end{array}$ & 32. 闘病中の負い目 & $\begin{array}{l}\text { 「長生きしてもらって嬉しかったけれど, 私のことばかり心配さ } \\
\text { せてばっかりやった. 負い目になっている. 主人の話をさせても } \\
\text { らったら泣いてしまう」(E) }\end{array}$ \\
\hline & & $\begin{array}{l}\text { 39. 故人への接し方に関する } \\
\text { 心残り }\end{array}$ & 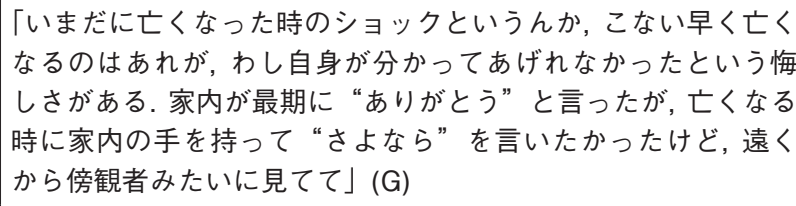 \\
\hline & & $\begin{array}{l}\text { 51. がん医療の知識のなさに } \\
\text { 対する後悔 }\end{array}$ & $\begin{array}{l}\text { 「他の病院に行ったら助かっていたのかもしれない. 私に知識が } \\
\text { あったら‥(J) }\end{array}$ \\
\hline & $\begin{array}{l}\text { 故人に想いを馳せる } \\
\text { こと }\end{array}$ & & $\begin{array}{l}\text { 「そんなことを色々と思い出しながらね, 仏壇の前で話しかけて } \\
\text { いるんです」(B) }\end{array}$ \\
\hline & & 62. 故人を思い出すこと & $\begin{array}{l}\text { 「旅行好きやったから,一緒に行ってたらどうかなとか, テレビ } \\
\text { とか見ててふと映ると思い出します.この繰り返し」(A) }\end{array}$ \\
\hline & & $\begin{array}{l}\text { 104. 故人に関する空想や願 } \\
\text { 望 }\end{array}$ & 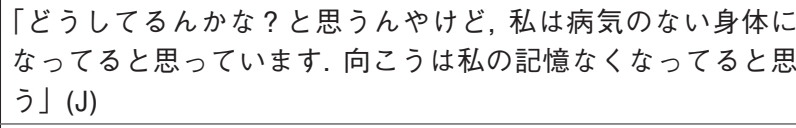 \\
\hline $\begin{array}{l}\text { 現実生活の } \\
\text { 情報交換 }\end{array}$ & $\begin{array}{l}\text { 故人の供養について } \\
\text { の疑問や迷い }\end{array}$ & 2. 毎日の供養 & $\begin{array}{l}\text { 「毎日仏壇にご飯供えて, お経読んで, 次やって, それで落ち着か } \\
\text { せているももある. 略) お酒で仏壇の前で晚酌毎日して. 今で } \\
\text { も時々. 主人はお酒が好きやったから」(F) }\end{array}$ \\
\hline
\end{tabular}


表 3 (続き)

\begin{tabular}{|c|c|c|c|}
\hline カテゴリー & サブカテゴリー & 概念 & バリエーション (具体例) \\
\hline \multirow{9}{*}{$\begin{array}{l}\text { 現実生活の } \\
\text { 情報交換 }\end{array}$} & \multirow[t]{3}{*}{$\begin{array}{l}\text { 故人の供養について } \\
\text { の疑問や迷い }\end{array}$} & 4. 納骨に関する疑問 & $\begin{array}{l}\text { 「去年 } 5 \text { 月末に主人の遺骨を納めました. 周囲の人に聞いたら, } \\
\text { 一周忌までは手元に置くっていう人とお墓に入れる人といろい } \\
\text { 万. 皆さんはどういうふうになってるのかとか, いろんな宗派や } \\
\text { 考え方でどういうふうにしているか. 自分の気が済むようにし } \\
\text { ていいのか」(J) }\end{array}$ \\
\hline & & 20. 遺品の整理に関する疑問 & $\begin{array}{l}\text { 「今でも家の中の遺品の整理ができていないんです. なんぼ整理 } \\
\text { しても捨てる物がない. 遺品いうんか, 鞄とか着るもん一杯あっ } \\
\text { て. 皆さん, どうしてるんですか ?」(G) }\end{array}$ \\
\hline & & 25. 遺産相続の問題 & $\begin{array}{l}\text { 「兄弟がいると想いが通じない. 兄弟だけだと話はすぐにっくけ } \\
\text { ど, 配偶者によって違うね. ちゃんと決めたことが, 墓に財産は } \\
\text { 均等に分けてとか. 一周忌終わって三回忌までは自分がお守し } \\
\text { ますが, 話し合いに入れてもらわないと困ると言っても納得し } \\
\text { ない. そういうのに詳しい方がいらっしゃったらお聞きしたい } \\
\text { です」(H) }\end{array}$ \\
\hline & \multirow[t]{2}{*}{ 悲嘆に対処する工夫 } & 42. 気そらしとしての外出 & $\begin{array}{l}\text { 「死んだことが信じられない思いがありますが, そういう思いが } \\
\text { 出てきた時は外に出る. クョクヨしても仕方がないから外に出 } \\
\text { るようにしているんです」(A) }\end{array}$ \\
\hline & & 43. 記録をつけること & $\begin{array}{l}\text { 「夫が死んで } 3 \text { 年間, 日記をつけています. 自分を慰めるのと, } \\
\text { 思い出にも残るし, つけてる. しょうもないことを書いてます } \\
\text { が」(B) }\end{array}$ \\
\hline & \multirow[t]{4}{*}{$\begin{array}{l}\text { 自分自身の健康状態 } \\
\text { について }\end{array}$} & 30. 死別後のさまざまな症状 & $\begin{array}{l}\text { 「今回のテーマの悲嘆で, すごく身に覚えがあります. 特に不眠. } \\
\text { 不眠は経験された方はあると思いますが, 不眠になると人でも } \\
\text { 動物でも一番こたえる. 悪循環になる可能性がある」(I) }\end{array}$ \\
\hline & & 84. 服薬に対する思い & $\begin{array}{l}\text { 「軽いうつと言われて, 先生が “どないしますか? 薬をあれしま } \\
\text { すか?”と言うので, “自分でちゃんとします. 薬はいらないで } \\
\text { す”と」(E) }\end{array}$ \\
\hline & & 92. 毎日の食生活 & $\begin{array}{l}\text { 「私は家内から教えてもらってなかったが, 亡くなる } 1 \text { カ月前か } \\
\text { ら少しずつ訪問介護で掃除のおばちゃんに教えてもらってたり. } \\
\text { 時には自分で. 平日はたいがい外食」(G) }\end{array}$ \\
\hline & & 93. 睡眠について & 「皆寝れる？」(B)「私は眠剂飲んでる」(A) \\
\hline \multirow{4}{*}{$\begin{array}{l}\text { 死別後のナラ } \\
\text { ティブの再編 }\end{array}$} & \multirow[t]{2}{*}{$\begin{array}{l}\text { 死別後の家族関係の } \\
\text { 振り返り }\end{array}$} & $\begin{array}{l}\text { 137. 家族に迷惑をかけず長 } \\
\text { 生きしたい }\end{array}$ & $\begin{array}{l}\text { 「元気でいるなら長生きしていいと思うけど, ボケたりしたらね. } \\
\text { (略) 私の父も姉も } 86 \text { でボケて亡くなったから. でも足が立たな } \\
\text { くなったら迷惑かける. 本人はええらしいが, 娘に迷惑かけるの } \\
\text { が嫌」(E) }\end{array}$ \\
\hline & & 141. 家族との距離の取り方 & $\begin{array}{l}\text { 「息子が帰ってきても出会わなければ話さないし, すれ違っても } \\
\text { ご飯の話とかしかしないし. ほんと, ただの同居人. 頼られても } \\
\text { しんどいけど, 気にするのもしんどい. 一定のルール決めて」(J) }\end{array}$ \\
\hline & \multirow[t]{2}{*}{$\begin{array}{l}\text { これまでの人生の振 } \\
\text { り返り }\end{array}$} & $\begin{array}{l}\text { 58. 介護や看取りに関する振 } \\
\text { り返り }\end{array}$ & $\begin{array}{l}\text { 「“やっぱり自分は死ぬんやろうか” という言葉が最期にしや } \\
\text { べった言葉やと思う. わしの知らんところで娘と二人で亡くな } \\
\text { る4 月前から一生懸命延命をしてたんやね. 病院の治療結果 } \\
\text { とか一杯プリントアウトしてショクでした」(G) }\end{array}$ \\
\hline & & $\begin{array}{l}\text { 98. 故人との思い出に関する } \\
\text { 振り返り }\end{array}$ & $\begin{array}{l}\text { 「私は喧嘩というのはほとんどしたことがない. 向こうはお父さ } \\
\text { んというか, なんとなしに大人と子どものようだと思う. 振る舞 } \\
\text { い方とか. 甘えてたんだなと亡くなって思います. 旦那は大人 } \\
\text { やったんやなと思う.小さい頃から苦労してたから, 腹違いの兄 } \\
\text { 弟とか. 私は末っ子として育ったからわがままで, なんとなしに } \\
\text { それが影響してたんかなあって思う」(E) }\end{array}$ \\
\hline \multirow{3}{*}{$\begin{array}{l}\text { 体験を通した } \\
\text { 悲嘆反応の客 } \\
\text { 観化 }\end{array}$} & \multirow[t]{3}{*}{$\begin{array}{l}\text { 悲嘆に対する理解と } \\
\text { その付き合い方 }\end{array}$} & & $\begin{array}{l}\text { 「色々聞いたけれど, 伴侶を失うのが一番大きい悲嘆でしょ. } \\
\text { 色々あるのが当たり前」(A) }\end{array}$ \\
\hline & & 55. 悲しむことの肯定 & $\begin{array}{l}\text { 「一番印象に残ったのが, } 4 \text { 階の緩和で受け持ちの先生がいはっ } \\
\text { て, 書類をいただいた時に, 親としては悲しい気持ちで取りに } \\
\text { 行ったら, “ささん, そういう時は思いっきり泣いてもいいです } \\
\text { よ”と穏やかな声かけてもらったという経験がありました」(I) }\end{array}$ \\
\hline & & $\begin{array}{l}\text { 117. 悲嘆を抱えながら生きる } \\
\text { こと }\end{array}$ & $\begin{array}{l}\text { 「ずっと悲しいっていうのは残っていくと思いますが, 折に触れ } \\
\text { 思い出すのが供養になると思うんです」(A) }\end{array}$ \\
\hline
\end{tabular}


表 3 (続き)

\begin{tabular}{|c|c|c|c|}
\hline カテゴリー & サブカテゴリー & 概念 & バリエーション (具体例) \\
\hline \multirow{3}{*}{$\begin{array}{l}\text { 体験を通した } \\
\text { 悲嘆反応の客 } \\
\text { 観化 }\end{array}$} & 死別の合理化 & $\begin{array}{l}\text { 60. 夫が先に亡くなってよ } \\
\text { かった } \\
\text { 91. 自分を納得させること }\end{array}$ & 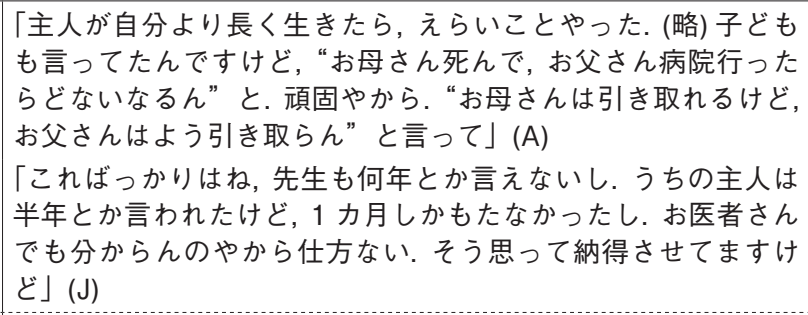 \\
\hline & 他者との比較 & $\begin{array}{l}\text { 82. 亡くした人による悲しみ } \\
\text { の違い } \\
\text { 119. 悲嘆の相対化 }\end{array}$ & $\begin{array}{l}\lceil 4 \text { 年前に亡くなったんだけど, 父親が亡くなったのは. 悲しい } \\
\text { けど, ここでわしががんばろうって. 母は } 93 \text { 歳. 天寿まっとう } \\
\text { して, 自分の妻が亡くなった時と全然感じ違う」(I) } \\
\text { 「普通に亡くなった場合に納骨とかやっててもあれなのに, 東北 } \\
\text { とかのあれで流された人とかどんなんかな, 悲しみとかどんな, } \\
\text { 受け入れられない」(A) }\end{array}$ \\
\hline & 悲嘆の回復 & 113. 悲嘆の回復 & 「自分のことですけど, だいぶん回復しました」(E) \\
\hline \multirow{5}{*}{$\begin{array}{l}\text { 死別後の肯定 } \\
\text { 的変化 }\end{array}$} & \begin{tabular}{|l|} 
死別後に実感した心 \\
情的変化
\end{tabular} & $\begin{array}{l}\text { 132. 命の大切さ } \\
\text { 133. 自分が生かされている } \\
\text { 感じ } \\
\text { 142. 自分だけではない }\end{array}$ & $\begin{array}{l}\text { 「正月前までは自分に自信なかったけど, 今は違う. なんか確か } \\
\text { に寂しいけど, 一人でおったことないし, 甘えたやし, 一人で生 } \\
\text { 活したことないからあかんと言われるけど, なんか今はやれる } \\
\text { 気がする」(E) } \\
\text { 「命の感謝は感じてるね. 重く感じてる. (略) 世間では自殺とか } \\
\text { あるけど, 命は大事やって聞かせたいですね」(F) } \\
\text { 「前からやけど, 主人が亡くなって余計に思う. 浄土真宗やから } \\
\text { かも. 生かされてる身やからって自分自身も感じてるから, 主人 } \\
\text { が亡くなって自分が生きてる感じ」(F) } \\
\text { 「主人が亡くなって, 自分だけがこんなふうに思ってたんでない } \\
\text { かと思ってたけど, そうではないと分かって皆にそうやって教 } \\
\text { えてもらえてよかった」(B) }\end{array}$ \\
\hline & $\begin{array}{l}\text { グループに参加して } \\
\text { 得た気づき }\end{array}$ & $\begin{array}{l}\text { 122. 体験を共有することの } \\
\text { 重要性 }\end{array}$ & $\begin{array}{l}\text { 「同じ思いをしている人とこうやって共有する場も大事やと思 } \\
\text { いますね」(A) }\end{array}$ \\
\hline & & $\begin{array}{l}\text { 124. 同じ体験をした人への } \\
\text { 接し方 }\end{array}$ & $\begin{array}{l}\text { 「勉強になりました. (略) どの言葉をかけたらいいのかって考え } \\
\text { ました. 無駄なことは言わない. 人の話を聴くのが一番だと思い } \\
\text { ます.自分自身も聴いてもらうのが一番. 言葉も必要なんです } \\
\text { が, 別にいらないのではないかと. (略) 人と話すときに慰めとか, } \\
\text { 安易に言うと傷つけることが分かったので, ここに来て」(A) } \\
\text { 「悲嘆という, すごくその人によって違うけれど, でも根本的に } \\
\text { は悲しみは同じではないかと」(A) }\end{array}$ \\
\hline & & 127. 大切な場 & $\begin{array}{l}\text { 「年数が経つにしたがって主人の話とかそういう話がしにくい } \\
\text { んですね. 年数経つと, 主人が生きてたこと言ったら, “生きてた } \\
\text { ら”という言葉をつけたら他の人から引かれるかもと. でもこ } \\
\text { こなら大丈夫. 話がしやすくて.ここなら主人の思い出の中にい } \\
\text { れる.こことかやっぱり話しやすいですね」(J) }\end{array}$ \\
\hline & & 129. 死の準備の必要性 & $\begin{array}{l}\text { 「自分の死準備は必要と思いました. 人間はいつか死ぬとか考 } \\
\text { えなかった. けど主人が死んで, 考えるようになりました. 準備 } \\
\text { しようと. 主人が先に亡くなってそういう経験をさせてもらっ } \\
\text { てよかった. 逆やったら考える機会なかったと思います」(A) }\end{array}$ \\
\hline \multirow[b]{3}{*}{$\begin{array}{l}\text { グループ相互 } \\
\text { 作用によるエ } \\
\text { ンパワメント }\end{array}$} & \begin{tabular}{|l|} 
メンバー間での受容· \\
共感・承認
\end{tabular} & $\begin{array}{l}\text { 45. メンバーのがんばりを認 } \\
\text { めること }\end{array}$ & $\begin{array}{l}\text { 「Jさんがここに来られただけでもすごいこと.あんまりそんな } \\
\text { ふうに思わないで」(A)〔他の参加者も「すばらしい」などロ々 } \\
\text { にほめる〕 }\end{array}$ \\
\hline & & 46. メンバーへの共感 & $\begin{array}{l}\lceil J さ ん も ね, \text { 自分一人でなんとかしなきゃってしんどくなるの } \\
\text { は, 弱いんじゃないかなって思うのかな」(F) }\end{array}$ \\
\hline & 他者との関わり & $\begin{array}{l}\text { 19. 他者と話をすることの重 } \\
\text { 要性 } \\
\text { 29. 誰かの役に立つこと } \\
\text { 88. 人とのつながりの重要性 }\end{array}$ & $\begin{array}{l}\lceil 人 に も \text { 言ってるの. 家に一人でいると話せないよって. 外に出 } \\
\text { ると誰かと会って話せるから」(L) } \\
\text { 「私のできること, 人にしてあげたらいいと思って. 前向きだと } \\
\text { 輪が広がるでしょ」(L) } \\
\text { 「仕事場に行けば様子を聞いてもらえたり, シルバーに行って } \\
\text { も. 老後の話をしたりして, 亡くしたら声をかけてもらって, 仕 } \\
\text { 事をもらったりして.やっばりそのつながりを大事にする. 世の } \\
\text { 中, 希薄になってるけど」(I) }\end{array}$ \\
\hline
\end{tabular}


男女における生活力の違い”, “135. 男性特有のつらさ”など, 故人との関係性や性差などの個別性についても話が及んだ. ま た, 〈死別後の生活の多忙と不安〉として死別直後から葬儀, 法 要, 相続など, 各種行事や手続きに追われ, 悲しむ間もない生活 を不安の中で送ってきた苦労を共有することもみられた. そし て〈今後の生活について摇れ動く気持ち〉として, “16. 前向き に生きなければならないという気持ち”もあれば “144. 前向 きになれない”現実もあることや, “112. 新しいことを始める ことへの罪悪感” など前に進みたいが進めないというジレン マを抱えていることも語られた.

\section{カテゴリー2:【故人に対する想いの表出】}

このカテゴリーは, 故人に対する過去の関わりについて内省 しつつ語られたものである.〈闘病から看取り, 死別に際して 感じた満足感や感謝〉として, “5. 看病できたことへの満足” や“52. 納得のいくがん医療を受けられたことに対する満足”, “99. 希望通りの葬式” などできることはしたという思いの表 明があった. また, 逆に〈闘病から看取り, 死別に際して感じた 否定的感情〉の表明もあり, “32. 闘病中の負い目” や“39. 故 人への接し方に関する心残り”など, 死別に際して後悔や罪悪 感を感じている人の意見も語られた。 それぞれの体験とその 語りは尊重される中で，故人に想いを馳せること〉へとつな がっていく.日々の生活で “40. 故人との対話”をしているこ とや “62. 故人を思い出すこと”などを語るようになる.いず れも感情を伴って語られることが多く, 未整理だった想いを整 理していく土台となっていたようである.

\section{カテゴリー 3:【現実生活の情報交換】}

このカテゴリーは現実的な問題について参加者同士で情報 交換し, 互いに励まし合いながら生活の知恵を共有していくと ころが特徵である. 一周忌を迎える人も多く〈故人の供養につ いての疑問や迷い〉について多くのやりとりがある. 日々の供 養の仕方から遺品の整理, 納骨, 相続問題, 墓の問題など, 次々 に直面する問題について参加者の実体験にもとづいた知恵の 共有がなされる. また, 〈悲嘆に対処する工夫〉についても, “42. 気そらしとしての外出” や “43. 記録をつけること”, その他に 友人をつくることや身体を動かすことなど, 参加者が実際行っ ている工夫についてエピソードを交えて話すようになる.さら に, 現実生活を支えていくうえで最も大切なこととして, 〈自分 自身の健康状態について〉も多く語られるようになる. “30. 死 別後のさまざまな症状” や不眠, 服薬, 食生活など各自が体験 を共有することで, 死別後の変化は自分だけではないというこ とが確認できたようである.

\section{カテゴリー 4: 【死別後のナラティブの再編】}

グループも中盤になってくると, 語りの様相が変わってく る.プログラム開始当初は強い感情を伴った【故人に対する想 いの表出】がなされていたが, 次第にくこれまでの人生の振り 返り〉がなされるようになる. それは死別体験だけでなく, 参 加者個人の生い立ちや, 故人との生活を振り返り, 新たに語り 直すことがみられるようになる. また, 〈死別後の家族関係の 振り返り〉についても話が出始める. “137. 家族に迷惑をかけ ずに長生きしたい”ことや “141. 家族との距離の取り方”な ど, 自分自身の生き方と家族との新たな関係性についての語り
に至る.これは死別後の寂しさと不安で出口の見えない語りか ら, 死別体験も含めた自分の人生を, 今後ざう生きていくかと いう新たなナラティブ (物語) を紡いでいく過程に入ったこと が分かる。

\section{カテゴリー 5:【体験を通した悲嘆反応の客観化】}

このカテゴリーは悲嘆反応に翻弄され, 出口の見えなかった 参加者の体験が, 学習や〈他者との比較〉によって整理されて くることに関連している. 〈悲嘆に対する理解とその付き合い 方〉として, “41. 悲嘆反応の一般化” や “55. 悲しむことの肯 定”などを通して, “117. 悲嘆を抱えながら生きること”への 言及がなされる.また, 〈死別の合理化〉を行ったり, 〈悲嘆の回 復〉に関する実感を語ったりするようになる.この段階ではあ る程度心の余裕を取り戻し, 悲嘆反応について客観的にみられ るようになっていることが伺える.

\section{カテゴリー 6:【死別後の肯定的変化】}

このカテゴリーはプログラム終盤に語られることが多い.グ ループ参加当初から終盤までを振り返り，〈グループに参加し て得た気づき〉が語られるようになる. “122. 体験を共有する ことの重要性”や“124. 同じ体験をした人への接し方”とし て, 話を聴くことの大切さや意見の押し付けが相手を傷つける ことがあるなどの気づきがみられた. また, グループ自体が他 にない “127. 大切な場” であったことが各メンバーから話さ れる. その中で〈死別後に実感した心情的変化〉が洞察された. その内容としては, 今後の生活について “128. 自信の芽生え” を感じたり, “130. 死別後の成長”を感じたことなどがある.ま た, 死別を体験することで逆に“132. 命の大切さ” や“133. 自 分が生かされている感じ”などを改めて実感するなどの変化 が生じている. そして, 死別は確かにつらいことだが“142. 自 分だけではない”という孤独感の払拭が, グループ体験から学 びとられていることが示唆された。

\section{カテゴリー7:【グループ相互作用によるエンパワメント】}

このカテゴリーは, プログラムの中で終始起こっていた相互 作用である.〈メンバー間での受容・共感・承認〉が繰り返さ れることで, 回を重ねるごとにグループの凝集性の高まりがみ られた. 信頼感や安心感が醸成される中でメンバーそれぞれの レベルに応じた自己開示を促し, 無理のない自己変容と気づき を生む土台となっていた. 最初は自分 1 人で抱えていた悲しみ が〈他者との関わり〉を通して変化していくことを参加者 1 人ひとりが感じていたようである.“19. 他者と話をすることの 重要性”や“29. 誰かの役に立つこと”など, 他者とつながる ことの大切さについての語りは当初からあったが, “75. 他人の 幸せを素直に喜べない自分”など素直に気持ちを表明し,メン バーに受け入れられることで, さらに信頼できる他者とのつな がりを実感したようである.

\section{3 ストーリーラインおよび概念図の作成}

以上の分析結果から, 遺族サポートグループにおいてどの ような変化が起こっているかについての概念図が作成された (図 1). カテゴリー 1 からカテゴリー 6 は, グループの中で話題 として語られやすい時期を便宜上図に示したが, 実際にはそれ ぞれ行きつ戻りつしながら展開するものである. また, カテゴ 


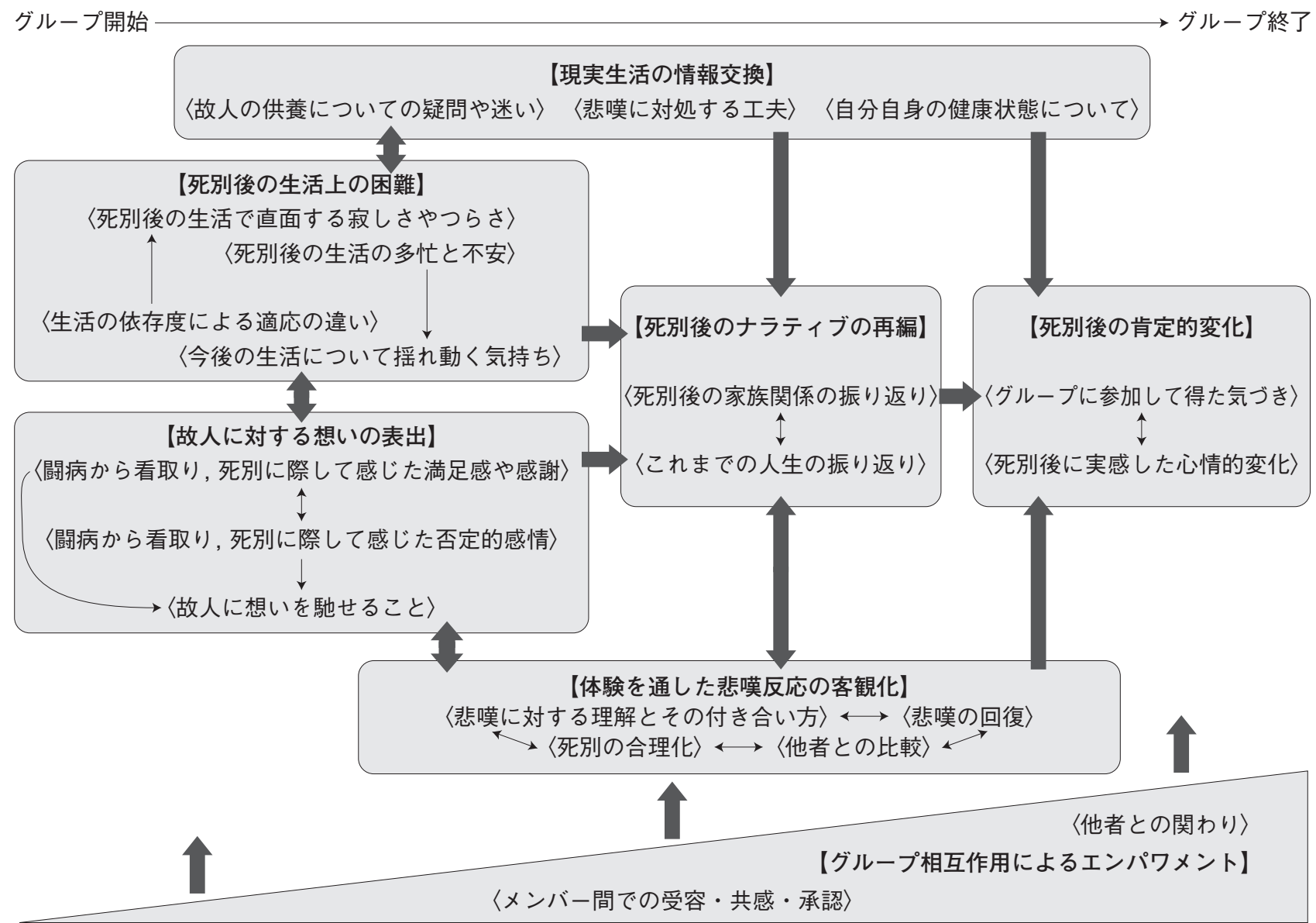

図 1 遺族サポートグループへの参加によって生じる変化に関する概念モデル

リー7 はグループ展開の土台となる部分である.

作成された概念図をもとに, 遺族サポートグループにおいて 生じる変化を概観すると, 当初から語られるのが【死別後の生 活上の困難】についてである.ある程度信頼関係ができ始める と【故人に対する想いの表出】が始まり, 普段の生活では語れ ない感情を伴った喪失志向の話題が語られるようになる.プロ グラム中盤では【現実生活の情報交換】も活発になり,メン バーそれぞれの体験から互いの生活上の知恵がやりとりされ る. また, 過去から現在に至る話を感情を伴いながら語る中で 【死別後のナラティブの再編】が徐々に起こり始める. プログ ラム後半には自分の思い, 他者の考え, 知識の獲得など視野が 広がることで【体験を通した悲嘆反応の客観化】や【死別後 の肯定的変化】について語られるという流れが見出された. そ して, その変化を下支えする形で【グループ相互作用によるエ ンパワメント】がプログラム当初から始まり, 回を重祇るごと にその支えの重要性をメンバーが実感するようになるという 過程が明らかになった。

\section{考察}

1 遺族サポートグループにおける参加者の心理プロセス

本研究は, 遺族サポートグループ参加者の語りから, グルー プに参加することで何が起こり, どのような変化が生じている のかを時間的流れに沿って示したものである.
まず, プログラム当初から語られる【死別後の生活上の困 難】では, 〈死別後の生活で直面寸る寂しさやつらさ〉や〈死 別後の生活の多忙と不安〉など故人のいない新しい環境に適 応することの困難が語られた.この「故人のいない世界に適応 寸ること」は Worden" ${ }^{9}$ の墾の課題IIIに相当するが, 個々人に よってその意味合いは異なり, 故人との関係性や故人の担って いた役割によってさまざまに影響を受ける. 本研究におけるグ ループ参加者の多くは配偶者を亡くしており, 〈生活の依存度 による適応の違い〉が浮き彫りになった. その一方で, グルー プの信頼関係が形成され始めると, 次第に【故人に対する想い の表出】が始まり, 闘病や看取り, 死別に際して感じたさまざ まな想いが感情を伴って語られるようになった. それらは故人 を峦った悲しみだけではなく, 満足感や感謝, 後悔や心残りな ど故人を巡るあらゆる肯定的・否定的感情が含まれる.このよ うに, 遺族が経験するさまざまな感情を自ら確認し味わうこと は, 喪の課題 II 9) の中心テーマである.

プログラム中盤になると,【現実生活の情報交換】が活発に なり, 故人の供養の仕方から自身の健康状態に至るまで各自が 疑問に思っていることや気になっていることに対して, 参加者 の体験にもとづいた知恵や工夫が共有されるようになる. その 一方で, 死別体験だけでなく参加者自身の生い立ちや故人との 生活を振り返り, 人生を新たに語り直す【死別後のナラティブ の再編】が徐々に始まる. 喪失をどのように意味づけ, 故人の いない新たなライフ・ストーリーをいかに再構成するかが, 遺 
された人が取り組まなければならない中心的な課題であり,そ のためには死別体験も含めた人生の語り (ナラティブ)が必要 となる ${ }^{10)}$.

さらに,プログラム中盤から終盤にかけて,【体験を通した悲 嘆反応の客観化】がみられ, 死別後に自分の身に起こっている さまざまな反応や変化を泠静にみつめることができるように なる. また, 悲しみは一生消えるものではないが, 悲嘆を抱えな がら生きていくことこそが亡くなった人への供養になるとい う発想の転換が図られるようになった。

プログラム終盤では, グループ全体を振り返り, 参加者同士 が互いに率直な気持ちを語り合い, ありのままの自分を受け入 れてもらえる安心安全な場であったことが確認され, グルー プを卒業することへの一抹の寂しさが表明された.これらのグ ループ体験を通して,「自分だけではない」という孤独感の払 拭と同時に, 命の大切さや自分が生かされているということを 改めて認識し, 自信や自己肯定感を取り戻していく【死別後の 肯定的変化】が見出された.

そして,グループで起こる変化の根底に流れていたものは 【グループ相互作用によるエンパワメント】であった. 参加者 同士が互いの発言に共感を示したり, 相手のがんばりを認める などの相互作用が繰り返されることで次第にグループの凝集 性が高まり, 結果として無理のない自己変容と気づきを生む土 台となっていたようである。

以上のような一連の過程は, 決して直線的に進むわけではな く,また参加者によってその進み具合はそれぞれに異なる。い ずれの時期においても, 全体として語られるテーマは現実生活 への対処に関する「回復志向コーピング」と大切な人の死そ のものに焦点を当てた「喪失志向コーピング」の両方を反復 しながら進んでいた ${ }^{11)}$ が, 同じグループの中でもかなり個人差 がみられた。

\section{2 参加者の心理プロセスを促進する要因}

遺族サポートグループ参加者の心理プロセスの分析で明ら かになったことは,【グループ相互作用によるエンパワメント】 が参加者の心理プロセスを促進する要因となっていたことで ある.この参加者の相互作用を最大限に引き出すためにグルー プはどのような役割を果たしていたのだろうか.

まず,グループが参加者にとって安全な場であり続けるため には,グループの構造を守ることが重要である. 曜日や時間, 頻 度などの時間的枠組みのほか, 筆者らのグループには参加者が 守らなければならない基本ルールを設けている. 基本ルールを 設定することで準拠枠となる構造を設けることになり, 参加者 に安心感をもたらすと同時に, ファシリテーターにとっても基 本ルールはグループを進展させていくうえで不可欠である ${ }^{9}$. また, ファシリテーターの基本姿勢, すなわち参加者 1 人ひと りの体験を尊重し傾聴する姿を見て, 参加者自身も仲間の体 験を尊重し傾聴する術を学ぶモデリングの効果もあったよう である.さらに, 筆者らのグループは参加者を固定した closed group であり, 毎回同じ顔ぶれが集まるのでセッションを重敉 るたびに参加者同士の信頼感が深まり, 親密感や安心感が増 す. それに加えて, 配偶者を亡くした遺族が参加者の大部分を 占めていたこともグループの凝集性を高めた要因として挙げ られるだろう。

参加者の心理プロセスを促進させた要因として,もう 1 つ考
えられるのはグループのプログラムの内容である. 筆者らのグ ループでは参加者の語り合いだけでなく, 悲嘆反応や回復のプ ロセスに関する心理教育と悲嘆の促進に有効な技法 (たとえ ば, 故人の思い出の品を持ち寄り語ることや, 故人に手紙を書 くことなど)を取り入れている. 自然で正常な反応に関する知 識や情報を提供することで, 参加者は「つらいのは自分だけで はない」という安心感をもつと同時に, 自身の状態を客観的に 把握し, 見通しをもって対処することができるようになる.ま た, 参加者に課題を与えることにより, 喪失の事実への直面化 を促したり, 感情表出を助け, 故人の死に対して意味づけを行 うのに役立ったのではないかと思われる. 参加者の語りにおけ る変化は小講義やワークの内容と連動しており, ある程度構造 化されたグループであるからこそ生じた変化であるといえよ う.

\section{3 本研究の限界と今後の課題}

本研究はごく少数の限られた参加者を対象としたものであ り, 本研究で見出された概念モデルを一般化するには限界があ る. また, 参加者の語りの変化が, グループに参加することに よる変化なのか, それとも死別からの時間経過に伴う変化なの かを特定しにくいという点が挙げられる. 今後は, 継続的にグ ループ実践を積み重㱛,引き続き検証していく必要がある。

謝辞 本研究は, 財団法人 笹川記念保健協力財団「2012 年 度 ホスピス緩和ケアにおける QOL の向上に関する研究助成」 を受けて実施した。

\section{文 献}

1) 坂口幸弘. わが国のホスピス・緩和ケア病棟における遺族 ケアの現状と課題一 2002 年度全国調査との比較. ホスピ ス・緩和ケアに関する調査研究報告書. 日本ホスピス・緩 和ケア研究振興財団. 2012; 1-8.

2) 大和田攝子, 加山寿也, 城下安代, 他. 緩和ケア病棟におけ る遺族ケアプログラムの実践. 心的トラウマ研究 2012; 8: 57-64.

3) 広瀬寛子. 悲嘆とグリーフケア. 医学書院, 東京, 2011; 65145.

4) 高松 里. サポート・グループの実践と展開. 金剛出版, 東 京, 2009; 15-30.

5) 大和田攝子, 大和田康二, 加山寿也, 他. 緩和ケア病棟にお ける遺族サポートグループの有効性の検討 (1)一精神症状 の軽減に果たす役割と限界. 第 18 回日本緩和医療学会学 術大会プログラム・抄録集. 2013; 423.

6) 広瀬寛子, 田上美千佳. 遺族のためのサポートグループに おける「思い出の品を持ってきて語ること」の意味一が んで家族を亡くした人たちの悲嘆からの回復過程への影 響. 日本看護科学会誌 $2005 ; 25: 49-57$.

7) Prigerson HG, Horowitz MJ, Jacobs SC, et al. Prolonged grief disorder: Psychometric validation of criteria proposed for DSMV and ICD-11. PLoS Med 2009; 6: e1000121.

8) 木下康仁. グラウンデッド・セオリー・アプローチの実践 一質的研究への誘い. 弘文堂, 東京, 2003.

9) Worden JW 著, 山本 力 監訳. 悲嘆カウンセリング. 誠信書 房, 東京, 2011. 
10) Niemeyer RA 著, 富田拓郎, 菊池安希子 監訳. 喪失と悲嘆の 心理療法一構成主義からみた意味の探究. 金剛出版, 東京, 2007.

11) Stroebe M, Schut H. The dual process model of coping with bereavement: rationale and description. Death Stud 1999; 23: 197-224.

著者の申告すべき利益相反なし 


\title{
Original Research
}

\section{Qualitative research on the psychological process and facilitating factors in the participants of a bereavement support group}

\author{
Setsuko Owada ${ }^{1)}$, Koji Owada ${ }^{2)}$, Toshinari Kayama ${ }^{3)}$ and Yasuyo Shiroshita ${ }^{4)}$ \\ 1) Department of Psychology, Faculty of Human Sciences, Kobe Shoin Women’s University, 2) Division of Clinical \\ Psychology, Amagasaki Co-op Hospital, 3) Department of Palliative Care, ditto, 4) Division of Nursing, ditto
}

\begin{abstract}
The purpose of this study is to examine the psychological process and facilitating factors in the participants of a bereavement support group in palliative care settings. The subjects were 12 group members. The data was analyzed by the Modified Grounded Theory Approach. 7 categories, 20 sub-categories and 145 concepts were produced and the following psychological process was identified for the group members: "the difficulties in living after the bereavement," "expressing their feelings toward the deceased," "information exchange about their real life," "reorganization of the narrative after the bereavement," "objectifying their grief through their experience," "positive changes after the bereavement". This study indicated that "empowerment through group interaction" improved the psychological process of group members.

Palliat Care Res 2013; 8(2): 254-63
\end{abstract}

Key words: bereavement support group, palliative care, Modified Grounded Theory Approach 